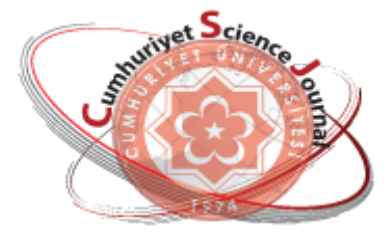

e-ISSN: $2587-246 X$

ISSN: $2587-2680$

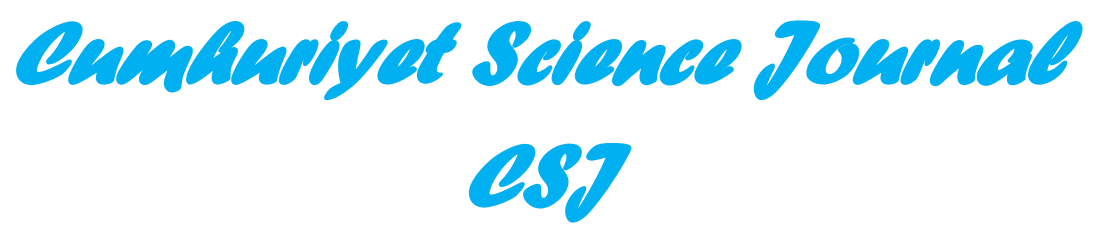

Cumhuriyet Sci. J., Vol.40-3(2019) 695-699

\title{
Antifungal Activity of Some Benzimidazole-Hydrazones
}

\author{
Ulviye ACAR ÇEVIK $^{1,2}$ (D), Derya OSMANIYY ${ }^{1,2 *}$ (i) \\ ${ }^{1}$ Department of Pharmaceutical Chemistry, Faculty of Pharmacy, Anadolu Universty, Eskişehir, Turkey \\ ${ }^{2}$ Doping and Narcotic Compounds Analysis Laboratory, Faculty of Pharmacy, Anadolu Universty, Eskişehir, \\ Turkey
}

\begin{abstract}
In the present work, 15 4-(1-(prop-2-in-1-yl)-1H-benzoimidazole-2-yl)- $N^{\prime}$ (substitutedmethylene)benzohydrazide derivatives $(\mathbf{4 a}-\mathbf{4 o})$ were re-synthesized to evaluate their antifungal activity. Structure identification of synthesized compounds was elucidated by ${ }^{1} \mathrm{H}-\mathrm{NMR},{ }^{13} \mathrm{C}-\mathrm{NMR}$, and HRMS spectroscopic methods. Inhibitory potential of the re-synthesized compounds was investigated against Candida supp. The compounds $\mathbf{4 e}$ and $\mathbf{4 l}$ showed significant anti fungal activity. Consistent with the activity studies, $\mathbf{4 e}$ was found to be potent derivative with its $\mathrm{MIC}_{50}$ value of $(1.95 \mu \mathrm{g} / \mathrm{mL})$ against Candida glabrata. And $4 \mathbf{I}$ was found to be potent derivative with its MIC $_{50}$ value of $(1.95 \mu \mathrm{g} / \mathrm{mL})$ against Candida krusei.
\end{abstract}

Keywords: Benzimidazole, Hydrazone, Antifungal activity, NMR, HRMS

\section{Bazı Benzimidazol-Hidrazonların Antifungal Etkinliği}

\begin{abstract}
Özet. Mevcut çalışmada, 15 4-(1-(prop-2-in-1-il)-1H-benzimidazol-2-il)- $N$ '-(sübstitüemetilen) benzohidrazit türevleri (4a-4o), antifungal aktivitelerini değerlendirmek üzere yeniden sentezlendi. Sentezlenen bileşiklerin yapı tanımlamaları ${ }^{1} \mathrm{H}-\mathrm{NMR},{ }^{13} \mathrm{C}-\mathrm{NMR}$ ve HRMS spektroskopik yöntemlerle açıklandı. Yeniden sentezlenen bileşiklerin antifungal etkinlikleri Candida türlerine karşı değerlendirildi. Bileşik 4e ve $\mathbf{4 l}$ önemli aktivite gösterdi. Aktivite çalışmaları ile uyumlu olarak, 4e bileşiği Candida glabrata'ya karşı $1.95 \mu \mathrm{g} / \mathrm{mL} \mathrm{MIC}_{50}$ değeri ile güçlü bir türev olarak bulundu. Aynı zamanda $4 \mathbf{l}$ bileşiği Candida krusei'ye karşı $1.95 \mu \mathrm{g} / \mathrm{mL}$ $\mathrm{MIC}_{50}$ değeri ile güçlü bir türev olarak bulundu.
\end{abstract}

Anahtar Kelimeler: Benzimidazol, Hidrazon, Antifungal aktivite, NMR, HRMS

\section{INTRODUCTION}

Life loss depending on fungal infections are more than 1.35 million per year worldwide [1]. Aspergillus spp., Cryptococcus neoformans and Candida spp. are still the three main pathogens of fungal infections. Over the last few decades, the occurrence of systemic fungal infections has increased considerably in immunocompromised hosts, particularly patients who receive cancer chemotherapy or patients with AIDS and undergone organ transplantation [1-3]. Some research teams stated that Candida albicans $(C$. albicans) which caused severe mucosal infections with potentially fatal invasive infections was the most common fungus in these patients $[4,5]$. On the other hand, only a restricted number of antifungal agents are formerly accessible to treat these life-threatening fungal infections [6]. Presently, clinical antifungal agents can be separated into four classes: Echinocandins (such as Micafungin and Caspofungin), antimetabolites (such as 5-fluorocytosine) polyenes (such as Nystatin and Amphotericin B) and azoles (such as Itraconazole and Fluconazole) [2,3].

\footnotetext{
* Corresponding author. Email address: dosmaniye@anadolu.edu.tr http://dergipark.gov.tr/csj C2016 Faculty of Science, Sivas Cumhuriyet University
} 
Azoles inhibits lanosterol 14- $\alpha$-demetilase enzyme; which is responsable for converting lanosterol into ergosterol. Ergosterol is the major component of fungal cytoplasmic membranes and responsable for bioregulation of membrane assymmetry [7]. Azoles are first-line drug for fungal infections due to their wide antifungal spectrum, high potency and low toxicity [8]. However, some problems remain, such as severe drug resistance, cytotoxicity. However, emergence of drug resistance, environmental hazards and other problems objectively indicate the urgent need for novel antifungal agents $[2,9]$.

Nitrogen heterocycles are common structural motifs in compounds with antifungal activity [4]. Benzimidazole that was an important heterocyclic nucleus that has been used extensively in medicinal chemistry is a component of vitamin B12 and is related to the DNA base purine and the stimulant caffeine. Substituted benzimidazole displays a broad spectrum of potential pharmacological activities such as antiinflammatory, anti-tubercular, anticancer, antibacterial, antiviral and antifungal activity. [57, 9, 10-17]. In addition to benzimidazole derivatives, hydrazone based compounds, which bear an azomethine $-\mathrm{NHN}=\mathrm{CH}$ - functional group, have showed antifungal activity $[18,19]$.

Based on the above information, antifungal activities of the compounds containing benzimidazole and hydrazone residues were the subject of curiosity. For this purpose, we resynthesized some benzimidazole-hydrazone based upon the studies that reported the antifungal potentials [20].

\section{MATERIALS AND METHODS}

\subsection{Chemistry}

All chemicals used in the syntheses were purchased either from Sigma-Aldrich Chemicals (Sigma-Aldrich Corp., St. Louis, MO, USA) or Merck Chemicals (Merck KGaA, Darmstadt, Germany). Melting points of the obtained compounds were determined by MP90 digital melting point apparatus (Mettler Toledo, $\mathrm{OH}$, USA) and were uncorrected. The IR spectra were obtained on a Shimadzu, IR Prestige-21 (Shimadzu, Tokyo, Japan). ${ }^{1} \mathrm{H}$ NMR and ${ }^{13} \mathrm{C}$
NMR spectra of the synthesized compounds were registered by a Bruker $300 \mathrm{MHz}$ and $75 \mathrm{MHz}$ digital FT-NMR spectrometer (Bruker Bioscience, Billerica, MA, USA) in DMSO- $d_{6}$, respectively. Splitting patterns were designated as follows: $s$ : singlet; d: doublet; t: triplet; $\mathrm{m}$ : multiplet in the NMR spectra. Coupling constants (J) were reported as Hertz. M+1 peaks were determined by Shimadzu LC/MS ITTOF system (Shimadzu, Tokyo, Japan). All reactions were monitored by thin-layer chromatography (TLC) using Silica Gel 60 F254 TLC plates (Merck KGaA, Darmstadt, Germany).

2.1.1. General procedure for the synthesis of target compounds (4a-4o)

In order to determine the antifungal activity, synthesis studies were carried out for compound 4a-4o. Synthesis studies was performed by means of previous study reported by our research group [20].

\subsection{Antifungal Activity}

The in vitro antifungal activities of all resynthesized derivatives $\mathbf{4 a}-\mathbf{4 o}$ were screened at between $1 \mu \mathrm{mg} / \mathrm{mL}-1.95 \mu \mathrm{g} / \mathrm{mL}$ concentrations using various Candida strains including $C$. albicans (ATCC 90030), C. glabrata (ATCC 90030) C. krusei (ATCC 6258) and $C$. parapsilopsis (ATCC 22019) and following the protocol of the EUCAST in keeping with the previous studies reported by our research group [21, 22].

\section{RESULTS AND DISCUSSIONS}

\subsection{Chemistry}

The compounds $\mathbf{4 a - 4 o}$ were re-synthesized as summarized in Scheme 1. Compound $\mathbf{1}$ was synthesized under microwave irradiation using 1,2-phenylenediamine and methyl 4formylbenzoate. Reaction of Methyl 4-(1Hbenzo[d]imidazol-2-yl)benzoate and propargyl bromide gave the compound 2 . Reaction of the methyl 4-(1-(prop-2-in-1-yl)- $1 H$ benzo[d]imidazole-2-yl)benzoate (2) and hydrazine hydrate gave 4-(1-(prop-2-in-1-yl)$1 H$-benzo[d]imidazole-2-yl)benzohydrazide (3). Reaction of compound 3 and aldehydes afforded to the target compounds $(\mathbf{4 a - 4 o})$. 
Structural elucidation of the synthesized compounds (4a-4o) was carried out by spectral analyses including IR, ${ }^{1} \mathrm{H}-\mathrm{NMR},{ }^{13} \mathrm{C}-\mathrm{NMR}$ and
HRMS. All the results of the analysis are in accordance with our previous report [20].

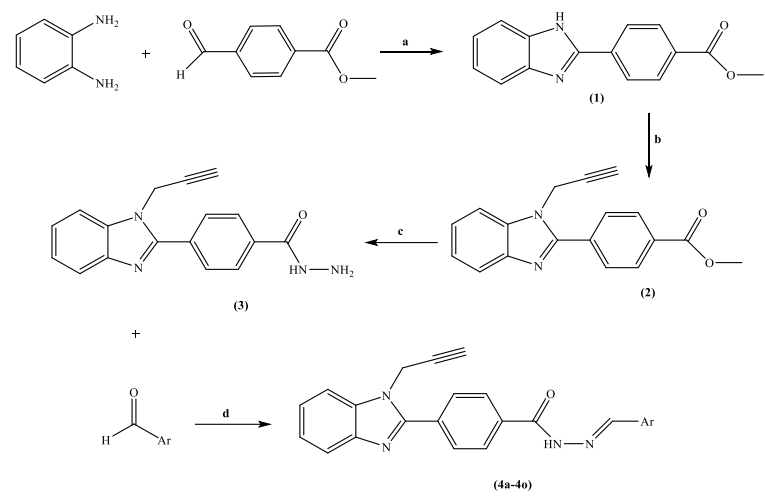

\begin{tabular}{cccc}
\hline Comp. & $\mathbf{A r}$ & $\mathbf{C o m p}$ & $\mathbf{A r}$ \\
\hline $\mathbf{4 a}$ & Thiophen-2-yl & $\mathbf{4 i}$ & 4-Methoxyphenyl \\
$\mathbf{4 b}$ & 5-Nitro-thiophen-2-yl & $\mathbf{4 j}$ & 2-Methoxyphenyl \\
$\mathbf{4 c}$ & Pyrrol-2-yl & $\mathbf{4 k}$ & 3-Methoxyphenyl \\
$\mathbf{4 d}$ & 1-Methyl-pyrrol-2-yl & $\mathbf{4 l}$ & 3-Hydoxyphenyl \\
$\mathbf{4} \mathbf{e}$ & Pyridin-3-yl & $\mathbf{4 m}$ & 3,5-Dihydoxyphenyl \\
$\mathbf{4} \mathbf{f}$ & 4-Fluorophenyl & $\mathbf{4 n}$ & 3,5-Dimethoxyphenyl \\
$\mathbf{4 g}$ & 4-Chlorophenyl & $\mathbf{4 o}$ & 2,3-Dimethoxyphenyl \\
$\mathbf{4 h}$ & 4-Hydroxyphenyl & & \\
\hline
\end{tabular}

Scheme 1: Synthesis way of the compounds $4 \mathrm{a}-40$. Reagents and Conditions: a: $\mathrm{Na}_{2} \mathrm{~S}_{2} \mathrm{O}_{5} / \mathrm{DMF}$, Microwave irradiation, 240 ${ }^{\circ} \mathrm{C}, 10$ bar, $5+5 \mathrm{~min}$. b: $\mathrm{NaH} / \mathrm{DMF}$, propargyl bromide, r.t, 20 h. c: $\mathrm{NH}_{2} \mathrm{NH}_{2} \cdot \mathrm{H}_{2} \mathrm{O}(\% 100)$, Microwave irradiation, $150^{\circ} \mathrm{C}, 10$ bar, 10 min. d: $\mathrm{EtOH} / \mathrm{CH}_{3} \mathrm{COOH}$, reflux, $2 \mathrm{~h}$.

Table 1. $\operatorname{MIC}_{50}(\mu \mathrm{g} / \mathrm{mL})$ values of compounds $\mathbf{4 a}-\mathbf{4 o}$.

\begin{tabular}{ccccc}
\hline Comp. & C. albicans & C. glabrata & C. krusei & C. parapsilosis \\
$\mathbf{4 a}$ & $>1000$ & $>1000$ & 62.50 & $>1000$ \\
$\mathbf{4 b}$ & $>1000$ & $>1000$ & $>1000$ & $>1000$ \\
$\mathbf{4 c}$ & $>1000$ & $>1000$ & 62.50 & $>1000$ \\
$\mathbf{4 d}$ & $\mathbf{1 . 9 5}$ & $>1000$ & $>1000$ & $>1000$ \\
$\mathbf{4 e}$ & 125 & $\mathbf{1 . 9 5}$ & $>1000$ & $>1000$ \\
$\mathbf{4 f}$ & $>1000$ & $>1000$ & $>1000$ \\
$\mathbf{4 g}$ & $>1000$ & $>1000$ & $>1000$ & $>1000$ \\
$\mathbf{4 h}$ & $\mathbf{1 . 9 5}$ & $>1000$ & $>1000$ & 15.63 \\
$\mathbf{4} \mathbf{4}$ & $>1000$ & $>1000$ & $>1000$ & $>1000$ \\
$\mathbf{4 j}$ & $\mathbf{1 . 9 5}$ & $>1000$ & $>1000$ & $>1000$ \\
$\mathbf{4 k}$ & $>1000$ & 1000 & $\mathbf{1 . 9 5}$ & $>1000$ \\
$\mathbf{4 l}$ & 15.63 & $>1000$ & 7.81 & $>1000$ \\
$\mathbf{4 m}$ & $>1000$ & $>1000$ & $>1000$ & $>1000$ \\
$\mathbf{4 n}$ & $>1000$ & 1.95 & 31.25 & $>1000$ \\
$\mathbf{4 0}$ & $>1000$ & 1.95 & 1.95 & $>1000$ \\
Ketoconazole & 0.98 & 1.95 & 1.95 \\
Fluconazole & 0.98 & & albicans $(A T C C$ & 0.98 \\
\hline
\end{tabular}

\subsection{Antifungal Activity}

According to the protocol of the EUCAST reported previously by our research group [21, 22], all obtained compounds $\mathbf{4 a - 4 o}$ were screened for their in vitro antifungal activity against four pathogenic fungi;
2001), C. krusei (ATCC 6258), C. parapsilosis (ATCC 22019). Ketoconazole and fluconazole were used as reference drugs. The results of antifungal activities are listed in Table-1. Compounds $\mathbf{4 d}, \mathbf{4 h}$ and $\mathbf{4 j}$ were determined to have $\mathrm{MIC}_{50}$ values of $1.95 \mu \mathrm{g} / \mathrm{ml}$ against $C$. albicans. On the other hand, Compounds $4 \mathbf{e}$ and 
4l were determined to have $\mathrm{MIC}_{50}$ values of 1.95 $\mu \mathrm{g} / \mathrm{ml}$ against $C$. glabrata and $C$. krusei, respectively. This $\mathrm{MIC}_{50}$ values is the same as the $\mathrm{MIC}_{50}$ values of reference drugs against $C$. glabrata and $C$. krusei. Compound $4 \mathbf{e}$ bearing pyridin-3-yl possessed good activity against $C$. glabrata with an MIC value of $1.95 \mu \mathrm{g} / \mathrm{mL}$. Compound 4l including 3-hydroxyphenyl possessed good activity against $C$. krusei with an MIC value of $1.95 \mu \mathrm{g} / \mathrm{mL}$. However compound $\mathbf{4 m}$ bearing 3,5-dihydoxyphenyl had weak antifungal activity. This information suggests that the hydroxy group brought to the fifth position of phenyl ring reduces the antifungal activity. The lack of activity of the methoxy-containing derivative in the third position of phenyl $(\mathbf{4 k})$ indicates that the replacement of the hydrogen and methyl group of the hydroxyl group decreases the This information suggests that hydroxyl hydrogen in the third position of phenyl ring enhances activity propably by making hydrogen bonds.

\section{CONCLUSION}

In summary, a series of benzimidazole-hydrazone derivatives were re-synthesized and evaluated for their antifungal activity. The primary results indicated that obtained compounds $\mathbf{4 a}-\mathbf{4 o}$ displayed antifungal activities within different ranges. Compounds $\mathbf{4 e}$ and $\mathbf{4 l}$ displayed significant activity against $C$. glabrata and $C$. krusei, respectively. Compound $\mathbf{4 e}$ bearing pyridine-3-yl and compound $\mathbf{4 l}$ bearing 3hydroxyphenyl came to the fore in the series. We assume that the aromatic ring bound to the hydrazone group contributes to the antifungal activity by means of long-pair electron in third position. However, if the hydroxyl group at position third of phenyl ring is replaced by a methoxy group, the activity decreases activity. This information suggests that the steric hindrance of the methyl group abolishes the effect of the long-pair electron, or that the hydroxyl hydrogen's ability to form hydrogen bonds contributes to activity.

\section{REFERENCES}

[1] Wang S.Q., Wang Y.F., Xu Z., Tetrazole hybrids and their antifungal activities, Eur. J.
Med. Chem., 170 (2019) 225-234.

[2] Zhao L., Tian L., Sun N., Chen Y., Wang X., Zhao S., Su X., Zhao D., Cheng M., Design, synthesis, and structure-activity relationship studies of 1-amino alcohol derivatives as broadspectrum antifungal agents, Eur. J. Med. Chem., 177 (2019) 374-385.

[3] Zhao S., Zhang X., Wei P., Su X., Zhao L., Wu M., Hao C., Liu C., Zhao D., Cheng M., Design, synthesis and evaluation of aromatic heterocyclic derivatives as potent antifungal agents. Eur. J. Med. Chem., 137 (2017) 96107.

[4] Lino C.I., de Souza I.G., Borelli B.M., Silverio Matos T.T., Santos Teixeira I.N., Ramos J.P., de Souza Fagundes E.M., de Oliveira Fernandes P., Maltarollo V.G., Johann S., de Oliveira R.B., Synthesis, molecular modeling studies and evaluation of antifungal activity of a novel series of thiazole derivatives, Eur. J. Med. Chem., 151 (2018) 248-260.

[5] Shi Y., Jiang K., Zheng R., Fu J., Yan L., Gu Q., Zhang Y., Lin F., Design, MicrowaveAssisted Synthesis and in Vitro Antibacterial and Antifungal Activity of 2,5-Disubstituted Benzimidazole, Chem. Biodiversity, 16 (2016) 1800510.

[6] Villa P., Arumugam N., Almansour A.I., Kumar R.S., Mahalingam S.M., Maruoka K., Thangamani S., Benzimidazole tethered pyrrolo[3,4-b]quinoline with broad-spectrum activity against fungal pathogens, Bioorg. Med. Chem. Lett., 29 (2019) 729-733.

[7] Karaburun A.C., Kaya Çavuşoğlu B., Acar Çevik U., Osmaniye D., Sağlık B.N., Levent S., Özkay Y., Atlı Ö., Koparal A.S., Kaplanciklı Z.A., Synthesis and Antifungal Potential of Some Novel Benzimidazole-1,3,4Oxadiazole Compounds, Molecules, 24 (2019) 191.

[8] Wu J., Ni T., Chai X., Wang T., Wang H., Chen J., Jin Y., Zhang D., Yu S., Jiang Y., Molecular docking, design, synthesis and antifungal activity study of novel triazole derivatives, Eur. J. Med. Chem., 143 (2018) 1840-1846.

[9] Si W.J., Wang X.B., Chen M., Wang M.Q., Lu A.M., Yang C.L., Design, synthesis, antifungal 
activity and 3D-QSAR study of novel pyrazole carboxamide and niacinamide derivatives containing benzimidazole moiety, New. J. Chem., 43 (2019) 3000.

[10] Kashid B.B., Ghanwat A.A., Khedkar V.M., Dongare B.B., Shaikh M.H., Deshpande P.P., Wakchaure Y.B., Design, Synthesis, In Vitro Antimicrobial, Antioxidant Evaluation, and Molecular Docking Study of Novel Benzimidazole and Benzoxazole Derivatives, J. Heterocycle. Chem., 56 (2019) 895.

[11] Yadav S., Lim S.M., Ramasamy K., Vasudevan M., Ali Shah S.A., Mathur A., Narasimhan B., Synthesis and evaluation of antimicrobial, antitubercular and anticancer activities of 2-(1-benzoyl-1H-benzo[d] imidazol-2-ylthio)-N-substituted acetamides, Chemistry Central Journal, 12-66 (2018) 1-14.

[12] Abdel-Wahab S.M., Abdelsamii Z.K., AbdelFattah H.A., El-Etrawy A.S., Dawe L.N., Swaroop T.R., Georghiou P.E., Synthesis of 2Aryl- and 2-Haloarylbenzimidazole-N1acetamido Conjugates and a Preliminary Evaluation of Their Antifungal Properties, ChemistrySelect, 3 (2018) 8106-8110.

[13] Chandrika N.T., Shrestha S.K., Ngo H.X., Tsodikov O.V., Howard K.C., GarneauTsodikova S., Alkylated Piperazines and Piperazine-Azole Hybrids as Antifungal Agents, J. Med. Chem., 61 (2018) 158-173.

[14] Vijey Aanandhı M., Anbhule Sachın J., Synthesis, Characterization, And Evaluation Of Antıfungal Properties Of Substituted Benzımıdazole Analog, Asian J. Pharm. Clin. Res., 11 (2018) 66-69.

[15] Li L.X., Jiao J., Wang X.B., Chen M., Fu X.C., Si W.J., Yang C.L., Synthesis, Characterization, and Antifungal Activity of Novel Benzo[4,5]imidazo[1,2-d][1,2,4]triazine Derivatives, Molecules, 23 (2018) 746.

[16] Eren B., Yılmaz Ö., Çetin G., Darcan C., Microwave Assisted Synthesis and Potent Antimicrobial Activity of Some Novel 1,3Dialkyl-2-arylbenzimidazolium Salts, Lett. Drug. Des. Discov., 15 (2018) 621-633.

[17] Liu H.B., Gao W.W., Tangadanchu V.K.R., Zhou C.H., Geng R.X., Novel aminopyrimidinyl benzimidazoles as potentially antimicrobial agents: Design, synthesis and biological evaluation, Eur. J. Med. Chem., 143 (2018) 66-84.

[18] Özkay Y., Tunalı Y., Karaca H., Işıkdağ İ., Antimicrobial activity and a SAR study of some novel benzimidazole derivatives bearing hydrazone moiety, Eur. J. Med. Chem., 45 (2010) 3293-3298.

[19] Küçükgüzel S.G., Mazi A., Sahin F., Öztürk S., Stables J., Synthesis and biological activities of diflunisal hydrazide_/hydrazones, Eur. J. Med. Chem., 38 (2003) 1005-1013.

[20] Can Ö.D., Osmaniye D., Demir Özkay U., Sağlık B.N., Levent S., Ilgın S., Baysal M., Özkay Y., Kaplacıklı Z.A., MAO enzymes inhibitory activity of new benzimidazole derivativesincluding hydrazone and propargyl side chains, Eur. J. Med. Chem., 131 (2017) 92-106.

[21] Rodriguez-Tudela J.L., Barchiesi F. Subcommittee on Antifungal Susceptibility Testing (AFST). EUCAST Definitive Document EDef 7.1: Method for the determination of broth dilution MICs of antifungal agents for fermentative yeast. Clin. Microbiol. Infect., 14 (2008) 398-405.

[22] Can N.Ö., Çevik U.A., Saglık B.N., Özkay Y., Atlı Ö., Baysal M., Özkay Ü.D., Can Ö.D., Pharmacological and Toxicological Screening of Novel Benzimidazole-Morpholine Derivatives as Dual-Acting Inhibitors, Molecules, 22 (2017) 1374. 